Virtual Mentor. January 2003, Volume 5, Number 1.

doi: 10.1001/virtualmentor.2003.5.1.pfor1-0301

Policy Forum

\title{
Physician-Assisted Suicide: The Law and Professional Ethics
}

\section{Although the U.S. Supreme Court has decided that physician-assisted suicide is a matter of states' rights, there are many ethical and legal issues still unresolved for physicians.}

Faith Lagay, $\mathrm{PhD}$

The 1997 US Supreme Court ruling regarding physician-assisted suicide is often misrepresented or misunderstood. The question before the court was specific: Are state laws that criminalize physician-assisted suicide unconstitutional? The high court ruled that such laws were not unconstitutional. That ruling, however, did not make physician-assisted suicide a crime throughout the land. It declared, rather, that legalizing or criminalizing physician-assisted suicide (PAS) was a matter of states' rights; that is, a matter for each state to decide for itself.

Three years prior to the high court's decision, Oregon voters had approved a referendum legalizing P-AS by a slim margin of 51 percent. Following the Supreme Court ruling, Oregon offered the question to voters again, in November 1997, this time receiving a 60 percent majority in favor of legalizing the practice.

Four states besides Oregon-Michigan, Washington, California, and Maine- -have asked voters about P-AS, and voters in all 4 have turned it down. On the Maine referendum ballot in 2002, the question asked succinctly and in plain English: "Should a terminally ill adult who is of sound mind be allowed to ask for and receive a doctor's help to die?" Maine voters said "no" (meekly) by a vote of 51.5 percent to 48.5 percent.

Forty-six states stand opposed to Oregon, formally criminalizing P-AS. Forty of them (most recently Ohio in November 2002) have passed statutes that prohibit the practice, and 6 prohibit it by common law. Three states-North Carolina, Utah, and Wyoming have neither criminalized nor legalized physician-assisted suicide.

Those who oppose the practice advance 2 main arguments: (1) legalizing physician-assisted suicide will cause pressure on terminal patients who fear their illness is burdensome--physically, emotionally, or financially--to their families or caretakers and, (2) as Maine Medical Society's executive VP Gordon Smith put it, "physician-assisted suicide goes against 2,000 years of medical ethics" [1]. Smith has a point. The current version of the AMA's 155-year old Code of Medical Ethicsprohibits physician-assisted suicide in the same strong language it uses in prohibiting physician involvement in euthanasia: "Physician-assisted suicide is fundamentally incompatible with the physician's role as healer, would be difficult or impossible to control, and would pose serious societal risks" [2].

In an attempt to override Oregon's Death with Dignity Act, the statute that regulates the legal use of P-AS, US Attorney General John Ashcroft issued a directive in November 2001 entitled "Dispensing of Controlled Substances to Assist Suicide." The directive asserts that assisted suicide is not "a legitimate medical purpose" for potentially lethal drugs classified under the Controlled Substances Act. Under the directive, doctors who use these drugs to assist suicide are subject to having their federal narcotics licenses suspended or revoked. The directive caused much consternation, even among physicians who do not support and would not participate in P-AS, because it puts at risk all doctors who prescribe narcotics for management of intractable, end-of-life pain. A large part of the medical community expressed the fear that the directive would undo years of work spent in overcoming fears of addiction and securing adequate pain 
relief for patients. In April of 2002, US District Judge Robert Jones put a permanent restraining order on the Ashcroft Directive, explaining that Ashcroft had "overstepped the authority of the federal Controlled Substances Act when he declared that physician-assisted suicide was not a 'legitimate medical purpose'" [3]. The US Attorney General's Office has said it will appeal Judge Jones's ruling.

\section{Law versus Professional Ethics}

That a state can legalize physician-assisted suicide, as Oregon has done, highlights the difference between what is legal and what is ethical; what the state allowsresidents to do and what members of a given profession, in this case medicine, believe they ought to do. Though a state may legalize physician-assisted suicide—or abortion, or capital punishment, for that matter - it cannot force doctors who oppose the practice on grounds of professional ethics or personal beliefs to participate. There is a difference between what voters want and what constitutes sound medical practice, according to Gregory Hamilton, MD, co-founder and past president of Physicians for Compassionate Care, a group that opposes P-AS. "It's up to the medical profession-not Judge Jones or the voters of Oregon-to decide what's a legitimate medical practice," Hamilton said [3].

\section{Why Some Physicians Help}

Most terminally ill patients who wish to commit suicide want to do so by medical means, nonviolently, out of respect for themselves and others. Yet medical suicide is not easy to accomplish; dosage and timing of drug administration matter critically, especially if the drug is taken orally, and failed attempts can cause greater trauma than death itself for the patient and caregivers. Patients may beg caregivers to complete their failed attempt at dying. These circumstances and possible consequences convince some physicians that helping a patient who is determined to end his or her life prevents a greater harm than it causes. Moreover, some believe that ending, at a patient's request, the physical pain and mental anguish from which that patient will not recover does not violate the spirit or goals of medical ethics.

\section{What Ethical Choices Does a Physician Have?}

If a state does legalize physician-assisted suicide, what choices do physicians in that state face? Must they opt either to (1) refuse aid to patients determined upon killing themselves, thus driving those patients to seek help from other, possibly unknown, physicians or inexperienced caregivers or (2) violate their profession's principal code of ethics?

There are many services physicians can provide a patient who asks for assistance in dying without violating professional ethics or personal beliefs. First, they must confront the task of presenting the most accurate prognosis. This is a difficult but critical task that only the physician can perform. It demands skill, experience, and courage. In Death Foretold, physician Nicholas Christakis emphasizes that the lack of a prognosis, or an inaccurate one, can lead patients to make bad choices near the end of life [4]. Next, physicians must carefully describe all possible treatment and palliative care optionsto the patient and discuss what he or she can expect as consequences of each of those care options, as well as the consequences of accepting no treatment or care. Physicians can also play a role in referring terminally ill patients to others--psychiatrists, hospice workers, clergy--who can evaluate their mental status and help them consider end-of-life decisions. Meanwhile, however, physicians should maintain their relationship with the patient, no matter what course the patient finally chooses, short of participating in suicide, if that is the patient's ultimate choice. Withdrawing and withholding treatment, including ventilator treatment, CPR, and even nutrition and hydration, at the express request of the patient or patient's surrogate are all within the bounds of professional practice, according the Code of Medical Ethics[5].

In 1997, the University of Pennsylvania's Center for Bioethics commenced a project called Finding Common Ground to explore, among other topics, how physicians should respond to requests for assistance in dying [6]. One report from the project examined whether physicians were the only professionals, or even the best professionals, to aid in helping terminally ill patients end their lives [7]. The report concluded that doctors played a necessary but not a sufficient role. Physicians are best equipped among health care professionals to determine the patient's diagnosis, prognosis, and full range of treatment options. These activities in themselves, of course, do not violate the AMA Code of Medical Ethics that prohibits physician assistance with suicide: they are professional services rendered to all patients. The remaining 
activities that, according to the report, patient suicide should entail are: preparing the person for dying, providing the means, providing support during administration of the medications and while the patient is dying, managing complications, reporting the assisted suicide, and coordinating the overall process. These need not be carried out by physicians. Even prescribing of the drug could fall within the professional purview of nurse practitioners and physician assistants. In addition to health care professionals, clergy, social workers, and other counselors could participate. In this case, each of these health care professions would face the ethics question that physicians now confront and on which the AMA has taken a stand.

\section{The Advocacy Role of Physicians}

Many believe that when law and professional ethics come into conflict physicians have obligations beyond their oneon-one covenant with patients. Alex Capron and Eliot Friedson, for example, have written that physicians have a social and political duty to create an environment that encourages the ethical practice of medicine [8]. On this view, physicians should support and campaign for regulations that ensure humane care for the terminally ill and reimbursement for the costs of proper end-of-life care. Such provisions will reduce patients' concerns that their end-oflife care is overwhelmingly burdensome to others.

Physicians should also consider how best to care for and respond to those competent, terminally ill individuals in intractable pain who wish to die without spending days or weeks paralyzed from pain-killing medication or comatose and who desire help from medical professionals in doing so. The number of individuals in this category should remain few, but there will always be some. It is desirable to have guidelines and practices in place that allow health care professionals to respond legally and ethically.The absence of such guidelines, promotes unethical behavior among those who are genuinely trying to do what they deem best for their patients.

\section{References}

1. Scott G, Assisted-suicide foes, AMA, defeat Maine ballot initiative. Physician's Weekly.Dec 4, 2000. Available at: http://www.physweekly.com/archive/00/12 04 00/itn1.html. Accessed Dec 18, 2002.

2. Opinion 2.211 Physician-Assisted Suicide. American Medical Association. Code of Medical Ethics 2008-2009 Edition. Chicago, IL: American Medical Association; 2008:104-112. Google Scholar

3. Robeznieks A. Ruling preserves assisted suicide in Oregon-for now. Amednews.com. Available at http://www.amednews.com/2002/prsc0506. Accessed December 12, 2002.

4. Christakis NA. Death Foretold.Chicago: University of Chicago Press; 1999:7. View Article PubMed Google Scholar

5. Opinion 2.20 Withholding or Withdrawing Life-Sustaining Medical Treatment. American Medical Association. Code of Medical Ethics 2008-2009 Edition. Chicago, IL: American Medical Association; 2008:82-101. Opinion 2.22 Do-Not-Resuscitate Orders. American Medical Association. Code of Medical Ethics 2008-2009 Edition. Chicago, IL: American Medical Association; 2008:113-117. Google Scholar

6. Synder L, Caplan AL. Assisted suicide: finding common ground. Ann Intern Med. 2000;132: 468-469. Available at: http://www.annals.org/issues/v132n6/full/200003210-00007.html. Accessed December 12, 2002.

7. Faber-Langendoen K, Karlawish JHT. Should assisted suicide be only physician assisted? Ann Intern Med. 2000;132:482-487.

View Article PubMed Google Scholar

8. Friedson E. Professionalism and institutional ethics. In: Baker RB, Caplan AL, Emanuel LL, Latham SR, eds. The American Medical Ethics Revolution.Baltimore: The Johns Hopkins University Press; 1999:124-143; and Capron AM. Professionalism and professional ethics, " In: Baker RB, Caplan AL, Emanuel LL, Latham SR, eds. The American Medical Ethics Revolution. Baltimore: The Johns Hopkins University Press; 1999:180-191. Google Scholar 
The viewpoints expressed on this site are those of the authors and do not necessarily reflect the views and policies of the AMA.

(C) 2003 American Medical Association. All Rights Reserved. 